\title{
Narzędzia szacowania ryzyka powrotu do przestępstwa. Niezbędny instrument postępowania wykonawczego
}

\author{
TOMASZ KaLISZ \\ ORCID: 0000-0002-9751-3616 \\ Katedra Prawa Karnego Wykonawczego \\ Wydział Prawa, Administracji i Ekonomii Uniwersytetu Wrocławskiego
}

Postępowanie wykonawcze zbudowane jest z wielu tak zwanych postępowań incydentalnych, które składają się na faktyczny proces wykonywania orzeczeń zapadłych w szeroko rozumianym postępowaniu karnym. Przebieg tego postępowania determinuje wiele czynników związanych z celami stawianymi współcześnie przed karą kryminalną i towarzyszącymi jej środkami reakcji na przestępstwo. Wykonywanie kar musi uwzględniać strategie polityczno-kryminalne służące do kontroli zjawiska przestępczości, jednocześnie być procesem koncentrującym się na jednostkowym przypadku. Kontrola recydywy, poszukiwanie skutecznych środków oddziaływania na skazanych, mechanizmy diagnozowania i prognozowania jako podstawy decyzji w toku postępowania wykonawczego to bardzo charakterystyczne elementy współczesnych regulacji karno-wykonawczych i praktyki funkcjonowania organów postępowania wykonawczego. Zagadnienia te nabierają szczególnego znaczenia w perspektywie bardzo szczególnej kategorii skazanych, jaką są sprawcy przestępstw popełnianych pod wpływem zaburzenia preferencji seksualnych.

Nowa Kodyfikacja Prawa Karnego 54, 2019

(C) for this edition by CNS 
Ustawodawca, wprowadzając do kodyfikacji karnych odrębny model postępowania ze sprawcami przestępstw przeciwko wolności seksualnej popełnionych w związku z zakłóceniami czynności psychicznych o podłożu seksualnym, buduje go na karze pozbawienia wolności i leczniczych środkach zabezpieczających. Kara pozbawienia wolności w tych przypadkach powinna być realizowana na oddziale terapeutycznym o określonej specjalizacji ukierunkowanej na leczenie tego rodzaju zaburzeń. Pełne wykorzystanie możliwości, jakie stwarza pobyt skazanego w systemie terapeutycznym, powinno pozwolić na odstąpienie od wykonania środka zabezpieczającego. Skuteczna pomoc terapeutyczna to podstawa działań skierowanych wobec tego rodzaju sprawców. Istotna jest także odpowiednia ich motywacja do współpracy. Pozyskanie skazanego do aktywnego udziału w terapii często jest czynnikiem przesądzającym o jej skuteczności. Konstrukcja przepisów kodeksu karnego i kodeksu karnego wykonawczego (uzależnienie wykonania środka zabezpieczającego od efektów wcześniej wykonywanej kary oraz poprzedzenie decyzji o warunkowym zwolnieniu zasięgnięciem opinii biegłego) powinna ułatwić to zadanie wychowawcom i terapeutom. Wydaje się, że neutralizacja niebezpiecznych skłonności musi być pierwszoplanowym zadaniem podczas wykonywania kary pozbawienia wolności. Problematyka postępowania ze skazanymi z zaburzeniami preferencji seksualnych wymaga uruchomienia bardzo wielu instrumentów natury prawnej i organizacyjnej. Podejmując działania w sferze ograniczania tego typu przestępczości, a przede wszystkim w ramach terapii skazanych za przestępstwa o podłożu seksualnym, musimy zadbać o skoordynowanie środków natury jurysdykcyjnej, penitencjarnej i terapeutycznej. W ramach tej ostatniej trzeba na wstępie założyć, że dla skutecznego oddziaływania, przy uwzględnieniu istniejących trudności i barier, należy wykorzystać maksymalnie rozbudowany system oparty na wiedzy i instrumentarium pedagogicznym, psychologicznym, psychiatrycznym, a zwłaszcza seksuologicznym. Analizując rozwiązania kodeksowe, musimy pamiętać jeszcze o kontrowersyjnym ich uzupełnieniu, jakim jest procedura przewidziana w ustawie z dnia 22 listopada 2013 roku o postępowaniu wobec osób z zaburzeniami psychicznymi stwarzających zagrożenie życia, zdrowia lub wolności seksualnej innych osób, w postaci nadzoru prewencyjnego albo umieszczenia w Krajowym Ośrodku Zapobiegania Zachowaniom

Nowa Kodyfikacja Prawa Karnego 54, 2019

(C) for this edition by CNS 
Dyssocjalnym ${ }^{1}$. Wszystkie wskazane rozwiązania (prawnokarne i te wynikające ze specjalnej, wskazanej wyżej ustawy) operują mechanizmami terapeutycznymi i opierają się na wielu specjalistycznych ustaleniach i badaniach, które są podstawą zakwalifikowania do określonych grup skazanych czy też osób internowanych. Ze szczegółowych ustaleń związanych z badaniami osobowopoznawczymi wynika treść wykonywanych kar i środków. Wreszcie dla przebiegu wykonywania tych środków bardzo istotne znaczenia mają specjalistyczne diagnozy i prognozy zachowania w przyszłości.

Przestrzeń diagnostyczno-prognostycznych ustaleń jest obecnie jednym z najtrudniejszych praktycznych problemów związanych z tak zwanym zarządzaniem ryzykiem recydywy, a zwłaszcza indywidualną oceną prawdopodobieństwa powrotu do przestępstwa. Zarządzanie ryzykiem $\mathrm{w}$ tej przestrzeni to proces celowy, wymagający zaangażowania dużych sił i środków ekonomicznych oraz organizacyjnych, który powinien być oparty na doświadczeniu empirycznym. Dziś coraz skuteczniej potrafimy identyfikować ryzyka, które stwarzają sprawcy czynów zabronionych. Oprócz samej identyfikacji czynników recydywy ważne jest także ustalenie zakresu oraz siły oddziaływania czynników związanych z powrotem do zachowań kryminalnych. Wiedza w tym obszarze jest punktem wyjścia skutecznych form zarządzania wymiarem sprawiedliwości, a przede wszystkim podstawą wypracowania działań mających w jednostkowych przypadkach służyć do redukcji ryzyka recydywy. Brytyjski socjolog A. Giddens trafnie stwierdza, że w obliczu licznych zmian i niepewności co do otaczającego nas świata stale musimy podejmować ocenę grożącego nam ryzyka. Przestępczość zarówno w ujęciu zjawiska, jak i w indywidualnym przypadku jest jedną z najbardziej oczywistych odmian ryzyka, z jakimi spotykamy się współcześnie. Konieczność kontroli ryzyka to działania skierowane na jednostkę, ale także próba oddziaływania na całe społeczeństwa. Jednym z głównych zadań nowoczesnego państwa jest kontrola przestępczości. Zadanie to jest tym bardziej wyraźne, że stary paradygmat mówiący o możliwości zapewnienia pełnego bezpie-

1 Tekst jedn. Dz.U. z 2019 r. poz. 2203.

Nowa Kodyfikacja Prawa Karnego 54, 2019

(C) for this edition by CNS 
czeństwa obywateli zastępowany jest aktualnie koncepcją ukierunkowanej kontroli ryzyka².

Na strategię ograniczania przestępczości wyraźny wpływ mają także realnie liczone społeczno-ekonomiczne koszty przestępczości (między innymi straty majątkowe i osobiste ofiar przestępstw oraz publiczne i prywatne koszty zapobiegania przestępczości). Perspektywa ekonomiczna na pierwszym miejscu stawia przestępczość powrotną, generującą największe i w zasadzie stale odnawialne koszty ${ }^{3}$. Doświadczenia ostatnich dziesięcioleci (zwłaszcza wyniki badań empirycznych) uczą nas, że powinniśmy koncentrować się na rozwiązaniach i narzędziach, które są przedmiotem stałej ewaluacji i które wykazują praktycznie zweryfikowaną skuteczność w ograniczaniu recydywy. Jest to wyraźne odwołanie do evidence based criminal policy lub evidence based practice. Dominujące w strategiach walki z przestępczością powinny być działania i programy oparte na dowodach. Należy eliminować te fragmenty polityki kryminalnej, które mają charakter spekulatywny i wynikają z niepotwierdzonych założeń. Powinniśmy unikać niezweryfikowanych technik i metod pracy ze sprawcami przestępstw. Właściwą perspektywą jest paradygmat stałej ewaluacji i doskonalenia istniejących rozwiązań. Ważne jest poszukiwanie wiedzy o tym, co naprawdę działa, jakie środki i strategie zmniejszają ryzyko recydywy. Wiedza kryminologiczna i ekonomiczna ocena kosztów prowadzonych działań muszą zająć należne im miejsce i stać się, w jeszcze większym stopniu niż to ma miejsce dzisiaj, podstawą skuteczniejszych interwencji. Zadaniem niniejszego opracowania jest omówienie najistotniejszych problemów związanych z oceną poziomu ryzyka recydywy, przy uwzględnieniu metod aktuarialnych, metod psychometrycznych oraz idiograficznych badań klinicznych. Celem jest zwrócenie uwagi na narzędzia szacowania ryzyka powrotu do przestępstwa, przydatne zwłaszcza w zakresie wypracowywania skutecznych schematów interwencji.

Szacowanie ryzyka recydywy opiera się na wiedzy dotyczącej statycznych i historycznych czynników związanych ze zwiększonym prawdopodobieństwem powrotu do przestępstwa. Obecnie na ogół dobrze

2 A. Giddens, Socjologia, tłum. A. Szulżycka, Warszawa 2012, s. 241.

${ }^{3}$ R. Cooter, T. Ulen, Ekonomiczna analiza prawa, przeł. J. Bełdowski et al., red. J. Bełdowski, K. Metelska-Szaniawska, Warszawa 2009, s. 629 n.

Nowa Kodyfikacja Prawa Karnego 54, 2019

(C) for this edition by CNS 
potrafimy te czynniki ryzyka identyfikować. Na podstawie tak zebranej wiedzy dość skutecznie potrafimy także przeprowadzić statystyczną predykcję powrotu do przestępstwa. Niestety zdecydowanie gorzej radzimy sobie z programowaniem procesu oddziaływania na skazanych, gdzie chodzi o interwencję w przestrzeń cech i właściwości sprawcy, które powinny się zmienić, aby poziom ryzyka istotnie się zmniejszył. Doświadczenie ostatnich lat dowodzi, że ustrukturyzowana ocena ryzyka jest bardziej trafna niż nieustrukturyzowana diagnoza kliniczna ${ }^{4}$. Niezależnie od przyjętego modelu szacowanie ryzyka, co trafnie podkreśla B. Stańdo-Kawecka, polega na ustaleniu występujących u sprawcy obszarów problemowych, które w świetle badań empirycznych są skorelowane z przestępczością powrotną. Zachowanie przestępne jest determinowane wielką liczbą różnorodnych czynników zmieniających się i wzajemnie powiązanych. Teorie wyjaśniające oddziaływanie tych czynników nie mogą być uniwersalne i wykazują wyraźne zróżnicowanie poszczególnych kategorii przestępców. Prognozowanie sytuacji i zachowania osób nie jest proste, nie opiera się na bezwyjątkowych prawach ogólnych wyjaśniających przyczyny badanych zachowań. Dlatego szacowanie ryzyka może być ujmowane tylko jako prawdopodobieństwo, nigdy nie możemy stwierdzić, że konkretny badany z pewnością powróci do przestępstwa. To zastrzeżenie musi towarzyszyć wszystkim strategiom zarządzania ryzkiem powrotu do przestępstwa, zwłaszcza w kontekście skłonności do zbyt dalekiej ingerencji w sferę prawa i wolności potencjalnych recydywistów.

Diagnoza, prognoza czy szacowanie ryzyka od dawna są stałym elementem wymiaru sprawiedliwości. Procedury oceniania i formułowania wniosków co do przewidywanych przyszłych zachowań sprawców są podstawą wielu rozstrzygnięć w toku postępowania karnego. Początkowo dominowała diagnoza (prognoza) profesjonalna i nieustrukturyzowana, gdzie na podstawie swojej wiedzy i doświadczenia poszczególne podmioty (kuratorzy, sędziowie, psychologowie, psychiatrzy, terapeuci) sami decydowali o tym, jakie pytania i w jakiej kolejności zadać w trak-

${ }^{4}$ D. Wójcik, Stosowanie w postępowaniu karnym narzędzi diagnostyczno-prognostycznych stużacych oszacowaniu ryzyka powrotności do przestęstwa, Warszawa 2012, s. 10-18, https://www.iws.org.pl/pliki/files/IWS_W\%C3\%B3jcik\%20D_Ocena\%20ryzyka\%20ponownej\%20przest.pdf (dostęp: 1.03.2020).

Nowa Kodyfikacja Prawa Karnego 54, 2019

(C) for this edition by CNS 
cie prowadzonego (nieustrukturyzowanego) wywiadu. Co więcej, na tym etapie podejmowano decyzję także o tym, jakie inne dostępne informacje o skazanym uznać za istotne oraz jakie przypisać im znaczenie przy ustalaniu przyczyn popełnionego przez niego przestępstwa i prognozowaniu jego przyszłych zachowań ${ }^{5}$. Aktualnie punkt ciężkości przesuwa się wyraźnie w stronę aktuarialnych (statystycznych) narzędzi szacowania ryzyka oraz ustrukturyzowanych narzędzi klinicznych, wspartych metodami psychometrycznych pomiarów określonych cech osobowości, stanów afektywnych oraz dewiacji. Stan dyskusji w tym obszarze trafnie oddają słowa L.A. Craiga oraz K.D. Browna:

Pomimo wielości badań, które dowodzą, że metody aktuarialne odznaczają się większą trafnością predykcyjną niż diagnoza kliniczna, istotne ograniczenia miar aktuarialnych sprawiły, że specjaliści nadal nie osiągnęli konsensusu dotyczącego najlepszych metod łączenia czynników ryzyka w całościową ocenę ${ }^{6}$.

W zakresie diagnozy klinicznej podnosi się, że jest ona trudna do metodycznego ustrukturyzowania i bardzo uzależniona od osoby dokonującej oceny (determinanata indywidualnych doświadczeń diagnosty). Charakteryzując obraz klasycznych metod badań klinicznych, zwraca się uwagę na przewagę ustaleń dotyczących popełnionego przestępstwa i jego charakteru. Wyraźny jest tendencyjny, nacechowany osobistymi ocenami diagnosty obraz sprawcy, wynikający z posiadanego doświadczenia i stosowanych metod, używanej terminologii oraz zaklasyfikowania sprawcy do określonej grupy przestępców. Przeciwnym biegunem problemów metodycznych jest całkowite podporządkowanie prognozowania skalom statystycznym, co zdarza się w skrajnych modelach szacowania ryzyka opartych na technikach aktuarialnych. Bezkrytyczna wiara w statystykę powoduje przesunięcie punktu ciężkości wyłącznie na czynniki ryzyka kosztem wyraźnego ograniczenia wartości predykcyjnej tak zwanych zasobów ochronnych, tkwiących po stronie zarówno sprawcy, jak i systemu wymiaru sprawiedliwości. W takim ujęciu wyraźnie osłabiamy moc oddziaływań resocjalizacyjno-terapeutycznych stosowanych

5 B. Stańdo-Kawecka, Wybrane problemy profesjonalizacji organów probacyjnych i klasyfikacji sprawców oddanych pod dozór do grup ryzyka, „Nowa Kodyfikacja Prawa Karnego" 33, 2014, s. 20.

${ }^{6}$ L.A. Craig, K.D. Browne, Metody oceny ryzyka recydywy przestępstw seksualnych, „Dziecko Krzywdzone. Teoria, badania, praktyka” 6, 2007, nr 1, s. 3-12.

Nowa Kodyfikacja Prawa Karnego 54, 2019

(C) for this edition by CNS 
wobec skazanych, ryzykujemy wyraźnie błąd ekologiczny (wynik grupy w pełni przenosimy na jednostkę) i nie uwzględniamy okoliczności zewnętrznych mogących oddziaływać na człowieka, redukując ryzyko powrotu do przestępstwa ${ }^{7}$.

Wyraźny jest w ostatnim okresie proces specjalizacji poszczególnych narzędzi i technik szacowania ryzyka. Co więcej, opracowywane metodyki szacowania ryzyka przewidują coraz częściej oprócz narzędzi statystycznych wykorzystywanie tak zwanych narzędzi psychometrycznych pomiarów różnych cech i stanów psychicznych (zwłaszcza wobec pewnych grup skazanych - przestępstwa seksualne oraz przypadki związane z zachowaniami przemocowo-impulsywnymi i niestabilnym trybem życia) ${ }^{8}$. Testy, skale czy też kwestionariusze psychometryczne to wystandaryzowane i zobiektywizowane narzędzia pomiaru cech osobowości, stanów afektywnych oraz dewiacji. Na podstawie odpowiedzi i zachowań osoby badanej w sytuacji testowej pozwalają one wnioskować o jej zachowaniu w sytuacjach pozatestowych, życiowych. Jest to typowa i popularna metoda badań psychologicznych i seksuologicznych ${ }^{9}$. Uzyskujemy w ten sposób informację na temat procesów, jakie zachodzą w umyśle człowieka, poznajemy reakcje i identyfikujemy mechanizmy zachowań. Badania psychometryczne identyfikują mocne strony i obszary, które wymagają dalszego rozwoju. Narzędzia tego rodzaju mogą badać zdolności, umiejętności oraz osobowość człowieka. Pokazują, jakie są typowe style zachowania poszczególnych osób, czynniki motywujące, podstawowe obawy, wartości czy charakterystyczne reakcje. Ustrukturyzowana, spójna forma narzędzi kwestionariuszowych umożliwia rzetelne przeprowadzenie badania i uzyskanie wiarygodnych wyników przy jednoczesnym zaoszczędzeniu czasu (w porównaniu z przeprowadzaniem wywiadu) ${ }^{10}$.

7 R. Rogers, The Uncritical Acceptance of Risk Assessment in Forensic Practice, „Law and Human Behavior” 24, 2000, nr 5, s. 595-603.

${ }^{8}$ A.R. Beech, T. Ward, The integration of etiology and risk in sexual offenders: A theoretical framework, ,Aggression and Violent Behavior” 10, 2004, z. 1, s. 31-63.

9 M. Janus, A. Szulc, Seksuologiczne narzędzia diagnostyczne w Polsce i na świecie, ,Seksuologia Polska” 13, 2015, nr 1, s. 31-35.

10 Doskonałym przykładem kompleksowych mechanizmów szacowania ryzyka jest tak zwana ustrukturyzowana profesjonalna ocena (SPJ, stuctured proffessional judgement). Wskazany przykład koncentruje się na ocenie i zarządzaniu ryzykiem przemocy. Składa się z siedmiu etapów: 1. zbierania informacji, 2 i 3. określenia obecności i istotno-

Nowa Kodyfikacja Prawa Karnego 54, 2019

(C) for this edition by CNS 
Wydaje się, że najlepszym rozwiązaniem jest tak zwane kompleksowe podejście do szacowania ryzyka, polegające na uruchomieniu nomotetycznych przewidywań na podstawie danych aktuarialnych, wsparte psychometrycznymi pomiarami i oceną psychopatologii, która zbliżona jest do analizy idiograficznej. Badania kliniczne muszą jednak być bardziej ustrukturyzowane i w miarę możliwości weryfikowane w badaniach empirycznych. Warto także uwzględniać gamę czynników dynamicznych wpływających bezpośrednio i pośrednio na poziom ryzyka. Zaletą dobrze przeprowadzonych badań klinicznych jest możliwość uwzględnienia w procesie szacowania ryzyka danych dotyczących osobowości, postaw, właściwości i warunków osobistych sprawców oraz danych związanych $\mathrm{z}$ ich zachowaniem po popełnieniu przestępstwa i w trakcie wykonywania kary. Informacje te są bardzo pożądanym materiałem nie tylko ze względu na potrzeby resocjalizacyjno-terapeutyczne, są w istocie nośnikiem informacji o ryzyku recydywy. W procesie szacowania dostarczają nam bowiem informacji o dynamicznych zmianach, jakie mogą wpływać negatywnie bądź pozytywnie na poziom ryzyka. Badania kliniczne to źródło informacji o zmiennych dyspozycyjnych i kontekstowych. Czynniki te powinny być oceniane w układzie dynamicznym, obejmującym przeszłość, teraźniejszość oraz przyszłe zmiany (możliwe przekształcenia). Wyraźnie należy zaznaczyć, że w niektórych przypadkach szczególnie cenne będą właśnie zmiany obserwowane u skazanego, oczekiwane zwłaszcza w perspektywie prowadzonych oddziaływań związanych z zastosowaną sankcją. Znaczenie mogą mieć także zdarzenia, czasem zupełnie niezależne od tego oddziaływania, które są następstwem kolejnych etapów życia każdego człowieka. Ocena zachowania skazanego w toku

ści czynników ryzyka, 4. stworzenia opracowania dotyczącego ryzyka przemocy, 5. opracowania scenariuszy przemocy, 6. opracowania planów zarządzania danym przypadkiem na podstawie tych scenariuszy i 7. opisania wniosków końcowych. Narzędzie to jest przykładem łączenia podejścia aktuarialnego z doświadczeniem klinicznym, pozwala na bardziej indywidualne podejście do danego przypadku. Metody oceny oparte na modelu SPJ mają szerokie zastosowanie w wielu obszarach praktycznych i są używane na świecie od ponad 20 lat. Potrzeba zastosowania ich do oceny poziomu ryzyka wystąpienia zachowań związanych z przemocą, monitorowania postępów leczenia i planowania dalszej terapii jest widoczna i podkreślana przez wielu praktyków i badaczy w Polsce. Szerzej A. Welento-Nowacka, Zastosowanie oraz zatożenia teoretyczne narzędzi opartych na modelu ustrukturyzowanej oceny ryzyka wystapienia zachowań zwiazanych z przemoca $w$ praktyce klinicznej, „Psychiatria” 14, 2017, nr 1, s. 21-27.

Nowa Kodyfikacja Prawa Karnego 54, 2019

(C) for this edition by CNS 
odbywania kary powinna być uwzględniana w procesie szacowania ryzyka, jednocześnie musi mieć charakter kompleksowy, a jednostkowe incydenty powinny być oceniane we właściwej skali. Postępowanie wykonawcze to bardzo cenny etap z punktu widzenia procesów diagnostyczno-prognostycznych, dobrze udokumentowany. Materiały zgromadzone w toku wykonywania kar i środków reakcji na przestępstwo to często specjalistyczne opinie, różnego rodzaju diagnozy oraz cykliczne oceny, które dostarczają cennej wiedzy na temat skazanego.

Tam, gdzie szerokie zastosowanie znalazły narzędzia statystyczne, po początkowym okresie bezkrytycznych zachwytów zaczęto podchodzić do ich wykorzystywania bardziej racjonalnie, biorąc pod uwagę wady i zauważone problemy tej metody pomiaru ryzyka powrotu do przestępstwa. Zrezygnowano z założenia, że może powstać w pełni uniwersalne narzędzie, adekwatne i sprawdzalne wobec wszystkich grup przestępców. Populacje sprawców znacząco różnią się, istotny dla obrazu jest czynnik czasu (zmiany w obrazie, dynamice i charakterystyce przestępczości). Już chociaż z tych dwóch wymienionych powodów predykatory oceny muszą być stale weryfikowane i dostosowane do konkretnych grup skazanych. Nie możemy zapominać, że miary statystyczne przedstawiają jedynie probabilistyczny obraz ryzyka. Sumując, warto wyraźnie zaznaczyć, że obraz ryzyka wynikający z ustaleń aktuarialnych to jedynie stopień prawdopodobieństwa wystąpienia konkretnego zachowania w danym czasie u osób podobnych do grupy odniesienia będącej podstawą ustaleń nomotetycznych. Interpretacja wyników testów aktuarialnych musi być dokonywana z należyta rezerwą. Od strony czysto technicznych ustaleń musimy pamiętać o zmienności lub błędzie wiarygodności próby, a także zdawać sobie sprawę z tak zwanej ograniczonej ufności wobec zebranego materiału. Jak w każdych badaniach socjologicznych należy uwzględnić także wielkość statystycznych błędów. Jednym z istotnych problemów jest trafność prognozowania, która w zależności od stosowanych narzędzi oscyluje od 65\% do nawet $80 \%{ }^{11}$. W szacowaniu ryzyka recydywy istotna (oprócz łącznej trafności prognozowania) jest problematyka „fałszów pozytywnych” i „fałszów negatywnych”. Fałsz pozytywny — sytuacja gdy model przewiduje, że recydywa wystąpi, podczas gdy ona nie występuje. Z kolei fałsz

11 Porównaj dane przedstawione w opracowaniach oraz wyniki przedstawionych tam badań innych autorów: L.A. Craig, K.D. Browne, op. cit.

Nowa Kodyfikacja Prawa Karnego 54, 2019

(C) for this edition by CNS 
negatywny to stan, w ramach którego model przewiduje, że recydywa nie wystąpi, a rzeczywiście ma ona miejsce. „Fałsze pozytywne” to obciążenie głównie dla znajdujących się w systemie przestępców (surowsza kara, bardziej intensywny schemat oddziaływania, obawa przed stosowaniem środków probacyjnych czy też warunkowego zwolnienia). Z kolei „fałsze negatywne" to ryzyko powrotu do przestępstwa i koszty po stronie ofiar przyszłych przestępstw popełnionych przez źle zdiagnozowanych recydywistów. W obu wypadkach błędy szacowania mogą znacząco wpływać na ocenę prowadzonej polityki kryminalnej, a zwłaszcza na poziom zaufania do wymiaru sprawiedliwości ${ }^{12}$.

Interesującym rozwiązaniem pokazującym możliwości dobrze zaprojektowanego kompleksowego modelu szacowania ryzyka jest tak zwany model RNR (Risk-Need-Responsivity). Rozwijana od lat dziewięćdziesiątych XX wieku w Kanadzie, USA i Wielkiej Brytanii koncepcja odwołuje się do ogólnej teorii osobowości i społecznego uczenia się przy jednoczesnym uwzględnieniu elementów psychologii poznawczej. Przestępca to uczestnik procesu społecznego uczenia się, co do którego kluczowa jest analiza jego działań i ustalenie, jakie są jego myśli (konstruowanie myśli, ich przebieg oraz przekonania, oczekiwania i dążenia). Model przywiązuje wagę do roli i zakresu czynników sytuacyjnych, które mogą stymulować zachowania kryminalne lub tworzyć czynniki zabezpieczające. W ramach procesu orzekania, a zwłaszcza wykonywania kary istnieje możliwość rozpoznania czynników jednostkowych, międzyludzkich i społecznych, które mogą zwiększać ryzyko wchodzenia w konflikt z prawem ${ }^{13}$. W ocenie twórców koncepcji — J. Bonty, D.A. Andrewsa, R.D. Hoge'a ${ }^{14}$ — istnieje potrzeba oraz możliwość stworzenia tak zwanych narzędzi diagnostycznych, które są podstawą konstruowania efektywnych i skutecznych oddziaływań resocjalizacyjnych oraz programów probacyjnych ${ }^{15}$. Anali-

12 K. Kądziołka, Społeczno-ekonomiczne determinanty przestępczości powrotnej. Wybrane problemy stosowania metod ilościowych do identyfikacji zależności, „Współczesna gospodarka" 7, 2016, z. 1, s. 81-94.

13 D.A. Andrews, J. Bonta, The Psychology of Criminal Conduct, New Providence 2010, s. 131-155.

14 D.A. Andrews, J. Bonta, R.D. Hoge, Classification for effective rehabilitation. Rediscovering psychology, „Criminal Justice and Behavior” 17, 1990, nr 1, s. 19-51.

15 M. Sztuka, Efektywność oddziatywań w zorientowanym korekcyjnie modelu instytucji penitencjarnej. Doświadczenia amerykańskie, „Czasopismo Prawa Karnego

Nowa Kodyfikacja Prawa Karnego 54, 2019

(C) for this edition by CNS 
zowany model zmierza do rozpoznania czynników warunkujących bądź ułatwiających przekraczanie norm, potrzeb, jakie występują po stronie skazanego, oraz podatności na bodźce i techniki pozwalające na redukcję poziomu zagrożenia recydywą. Wskazane elementy to trzy zasady: ryzyka (risk), potrzeb (need) oraz reaktywności (responsivity). Pierwszy etap to predykcja popełnienia czynu zabronionego przez jednostkę (ryzyko). Najczęściej mamy tu do czynienia z aktuarialną identyfikacją czynników zewnętrznych i wewnętrznych, które w ramach rozumowania nomotetycznego pozwalają przybliżyć etiologię, dynamikę i nasilenie zachowań przestępnych ${ }^{16}$. Wieloczynnikowa koncepcja przestępczości zakłada możliwość i potrzebę wyodrębniania tego rodzaju czynników (statystycznie istotnych) i analizowania ich w toku rozbudowanych badań diagnostycznych. Diagnoza powinna być realizowana na podstawie ustandaryzowanych i rzetelnych narzędzi, dzięki którym możemy klasyfikować sprawców do grup o niskim, średnim oraz wysokim poziomie ryzyka $^{17}$. Mechanizm ten nie powinien być jedynie źródłem selekcji negatywnej. To punkt startu projektowania i realizacji programu oddziaływań i społecznej readaptacji (wyznaczenie środków kontroli i wstępne zaklasyfikowanie pedagogiczne, zwłaszcza rozróżnienie grup: high risk offenders oraz low risk offenders $)^{18}$. A. Barczykowska podkreśla, że dostępne obecnie metaanalizy wskazują dość jednoznacznie, że w populacji sprawców przestępstw funkcjonuje spora grupa, która ze względu na niski stopień demoralizacji oraz wysoki poziom zasobów własnych, stanowiący istotny czynnik chroniący, nie wymaga włączania w wysoce strukturalizowane programy resocjalizacyjne. Zbyt pochopne zakwalifikowanie do nich może prowadzić do wzrostu zachowań przestępczych związanych

i Nauk Penalnych" 2007, z. 1, s. 313-326; M. Sztuka, Anachronizm i aktualność. Idea resocjalizacji w sporze o nowoczesność, Kraków 2013, s. 236-243.

16 J.K. Gierowski, Czynniki ryzyka i opiniowanie przemocy u adolescentów, „Farmakoterapia w Psychiatrii i Neurologii” 2005, nr 2, s. 117.

17 T. Kalisz, Kara pozbawienia wolności w perspektywie zasady ultima ratio. Oczekiwany zmierzch więzienia?, [w:] Prawo karne jutra - między pragmatyzmem a dogmatyzmem, red. W. Zalewski, Warszawa 2018, s. 130-137.

${ }^{18}$ D. Wójcik, Stosowanie w postępowaniu karnym narzędzi diagnostyczno-prognostycznych stużacych oszacowaniu ryzyka powrotności do przestępstwa, Warszawa 2012, s. 10-18, https://www.iws.org.pl/pliki/files/IWS_W\%C3\%B3jcik\%20D_Ocena\%20ryzyka\%20ponownej\%20przest.pdf (dostęp: 1.03.2020).

Nowa Kodyfikacja Prawa Karnego 54, 2019

(C) for this edition by CNS 
między innymi z procesem dyfuzji zachowań ${ }^{19}$. Podkreśla się także, że jest to ekonomicznie nieuzasadnione w perspektywie wysokich kosztów, jakie generują rozbudowane programy resocjalizacyjno-terapeutyczne ${ }^{20}$. Drugi krok to ustalenie potrzeb, czyli czynników mocno skorelowanych z przestępstwem, tak zwane criminogenics needs (negatywne determinanty i potrzeby występujące u skazanych). Zidentyfikowane dysfunkcje i bariery powinny być przedmiotem programów korekcyjnych i stanowić zasadniczy cel prawnokarnej interwencji ${ }^{21}$. Czynniki te to przedmiot od-

19 A. Barczykowska, [w:] A. Barczykowska, S. Dzierzyńska-Breś, M. Muskała, Systemy oddziaływań resocjalizacyjnych Anglii i Stanów Zjednoczonych Ameryki, Poznań 2015, s. 42 .

20 B. Stańdo-Kawecka, O koncepcji resocjalizacji w polskiej literaturze naukowej polemicznie, „Probacja” 2010, nr 1, s. 117.

21 Potwierdzone w perspektywie badań empirycznych i ustaleń statystycznych czynniki zaliczane do grupy tak zwanych kryminogennych dzieli się na ,,wielką czwórkę" (big four), czyli czynniki bardzo mocno wpływające na zachowania kryminalne (te czynniki wprost odnoszą się do przestępczości powrotnej). Wielka czwórka to: 1. antyspołeczne zachowania w przeszłości (zatrzymania, odpowiedzialność na zasadach przewidzianych dla nieletnich, nieudana probacja oraz łamanie warunków podczas zwolnień z zakładów poprawczych i zakładów karnych), 2. antyspołeczna osobowość (skłonność do zachowań impulsywnych, agresja i przemoc w relacji ze światem zewnętrznym, potrzeba mocnych wrażeń, wypracowane techniki manipulacji), 3. antyspołeczna postawa (internalizacja wartości, zasad, reguł związanych ze światem przestępczym, rozbudowany system racjonalizacji uzasadniający przestępczy styl życia, identyfikacja ze światem przestępczym), 4. antyspołeczna grupa odniesienia (powiązanie i mocna identyfikacja ze środowiskiem przestępczym, zakotwiczenie w podkulturze, braku możliwości lub potrzeby zerwania kontaktów ze środowiskami patologicznymi). Drugą grupę czynników nazywamy ,umiarkowaną czwórką" (moderate four) i zaliczamy do niej: 1. trudną sytuację rodzinną (charakter związku partnerskiego, poziom i częstotliwość konfliktów, struktura rodziny, zjawiska patologiczne, na przykład przemoc, znęcanie, brak należytej opieki nad małoletnimi), 2. środowisko szkolne i zawodowe (relegowanie ze szkoły, porzucenie szkoły, niski poziom wykształcenia i kwalifikacji, okresy bezrobocia, brak motywacji do pracy), 3. nieumiejętność zagospodarowania czasu wolnego (brak zainteresowań, brak potrzeby korzystania $\mathrm{z}$ istniejących w danej społeczności instytucji kultury i aktywnego wypoczynku), 4. używanie względnie uzależnienie od substancji psychoaktywnych. Pierwsze cztery to predyktory bardzo mocno związane z recydywą, można powiedzieć, że są one wpisane niemal w każdy schemat przestępczości powrotnej. Połączone obie grupy czynników określa się jako „centralną ósemkę” (central eight), która wpływa na aktywność przestępczą jednostki w przyszłości. Szerzej J. Chojecka, Model dla wszystkich? Spory wokół koncepcji szacowania ryzyka recydywy, „Resocjalizacja Polska” 2014, nr 7, s. 85-100; T. Kalisz, Kara pozbawienia wolności w perspektywie założeń modelu $R-N-R$

Nowa Kodyfikacja Prawa Karnego 54, 2019

(C) for this edition by CNS 
działywań wobec skazanych oraz wyznacznik ryzyka. W większości mają one charakter dynamiczny. Zatem możliwa jest ich modyfikacja przez manipulację bodźcami zewnętrznymi i wewnętrznymi ${ }^{22}$.

Model R-N-R uwzględnia także czynniki bezpośrednio niewpływające na zachowania przestępcze. Są tak zwane potrzeby niekryminogenne, a wśród nich takie czynniki, jak: szczęście, wiara we własne siły, otwartość na nowe doświadczenia, lęk, duchowość, samoocena, depresja, kultura, sztuka, kondycja fizyczna czy zdolności kreatywne. Te pozytywne czynniki nie mogą być samodzielną podstawą oddziaływań, nie są zasadniczym celem pracy ze skazanym. Warto je wykorzystywać jako czynniki motywacyjne i wzmacniające zasadniczy kierunek oddziaływań, który zawiera się w potrzebie eliminacji lub zasadniczego osłabienia czynników kryminogennych.

Zasada reaktywności to reaktywność ogólna (general responsivity), oznacza stosowanie w procesie oddziaływania na skazanych jedynie takich programów i technik, które są przedmiotem stałej ewaluacji i które wykazują empirycznie zweryfikowaną skuteczność w ograniczaniu recydywy. Działania podejmowane w praktyce powinny być oparte na dowodach, a te, którym brakuje podbudowy teoretycznej i empirycznej weryfikacji, muszą zostać usunięte. Słynna teza R. Martinsona „nothing works" w perspektywie analizowanej zasady zastępowana jest pytaniem „what works?"23. Model R-N-R to połączenie nauki i praktyki. Zakłada zewnętrzną ocenę wszystkich stosowanych procedur i programów. Ewaluacja ma służyć stałemu doskonaleniu narzędzi i metod, eliminowaniu błędów systemowych oraz podnoszeniu kompetencji podmiotów zaangażowanych w jego realizację. Dla prawidłowego funkcjonowania niezbędna jest współpraca środowisk naukowych oraz organów wymiaru sprawiedliwości i postępowania wykonawczego. Zasada reaktywności to również tak zwana podatność skazanego/reaktywność indywidual-

(Risk-Need-Responsivity), [w:] O stabilność kodeksu karnego w świetle realiów. Księga Jubileuszowa Profesora Stanisława Hoca, t. 1, red. D. Mucha, Opole 2018, s. 200-209.

22 A. Barczykowska, Zastosowanie modelu $R-N-R w$ diagnozie resocjalizacyjnej dorostych sprawców przestęsstw — rozwiąania angielskie, „Studia Edukacyjne” 2015, nr 34, s. 245.

23 F.T. Cullen, P. Gendreau, From Nothing Works to What Works: Changing Professional Ideology in the 21st Century, ,The Prison Journal” 15, 2001, s. 330-356.

Nowa Kodyfikacja Prawa Karnego 54, 2019

(C) for this edition by CNS 
na (specific responsivity), czyli zdolność do podjęcia i realizacji określonych programów. Stosowane środki i metody oddziaływania muszą uwzględniać możliwości sprawcy, jego styl uczenia się oraz osobnicze ograniczenia poznawcze. Wyznacznikiem działań powinny być realnie oceniane cechy społeczno-demograficzne, takie jak: wiek, płeć, pochodzenie. Działania powinny także uwzględniać motywację skazanych do zmiany i zawierać elementy zmierzające do jej wzbudzania. Reaktywność indywidualna związana jest z występowaniem u ludzi niepowtarzalnych cech, które mogą wpływać na efekty pracy resocjalizacyjnej. Ma to szczególne znaczenie dla projektowanych schematów oddziaływania i kwestii wzajemnego stosunku poszczególnych kierunków indywidualno-prewencyjnego oddziaływania sankcji.

Osobne problemy wynikają z próby uruchomienia narzędzi szacowania ryzyka w odniesieniu do sprawców przestępstw popełnionych pod wpływem zaburzenia preferencji seksualnych. Grupa sprawców tego rodzaju zachowań ma bardzo zróżnicowany charakter, a kategorie zaburzeń preferencji seksualnych obejmują bardzo różne zachowania, począwszy od zabójstwa na tle seksualnym, przez gwałt, pedofilię oraz dotyk o charakterze seksualnym, a skończywszy na ekshibicjonizmie i podglądactwie. Szczególnie niebezpieczni są sprawcy aktów pedofilskich i przemocowych zachowań seksualnych. Analiza poszczególnych przypadków przekonuje nas, że sprawcy ci mają różne motywacje, działają w różnych okolicznościach, różnią się pod względem cech osobniczych, osobowości, psychopatologii, funkcjonowania seksualnego, skłonności do ponawiania przestępstw i podatności na interwencje. Mimo tej różnorodności wydaje się, że możemy wyodrębnić cechy charakterystyczne, motywacje i sposoby postępowania wspólne dla niektórych przestępców seksualnych, a ich poszukiwanie i właściwa klasyfikacja mogą być bardzo przydatne w procesie konstruowania terapeutycznych programów oddziaływania oraz szacowania ryzyka recydywy, w kontekście ich powrotu do społeczeństwa, bądź zastosowania środków zabezpieczających. T. Ward i A.R. Beech podkreślają, że czynniki genetyczne i neurorozwojowe (działające w okresie rozwoju mózgu) oraz środowisko indywidualne, społeczno-kulturowe i fizyczne kształtują funkcjonowanie psychiczne (motywacje/emocje, działanie/kontrolę oraz percepcję/pamięć). Te czynniki są fundamentem i umożliwiają wyszczególnienie czynników bar-

Nowa Kodyfikacja Prawa Karnego 54, 2019

(C) for this edition by CNS 
dziej proksymalnych w stosunku do przestępstwa seksualnego (takich jak problemy emocjonalne, trudności społeczne, nieprawidłowe pobudzenie lub procesy poznawcze) ${ }^{24}$. Konsekwencje przestępstwa, przez wpływ na środowisko sprawcy, prowadzą z kolei do podtrzymywania, ugruntowywania się i eskalacji cech psychologicznych. Te ramy pasują do obecnych modeli ryzyka.

Specjaliści podkreślają, że czynniki ryzyka przemocy seksualnej to wzajemna korelacja/oddziaływanie cech związanych z ryzykiem przemocy seksualnej oraz cech pozwalających na kontrolę tego zagrożenia. Wyodrębnione i sklasyfikowane czynniki ryzyka przestępstw seksualnych grupowane są w ramach kliku uzupełniających się kategorii ${ }^{25}$. Pierwsza to elementy historyczno-statyczne, do których zalicza się cechy wrodzone, w dużej mierze stabilne, które służą do oceny niebezpieczeństwa powrotu do zachowań kryminalnych. Jest to grupa cech obecnych przy dowolnej ocenie ryzyka, dobrze służących do predykcji zagrożeń w dłuższej perspektywie. Historyczno-statyczne czynniki ryzyka powrotu do przestępstwa seksualnego mają podwójny charakter. Grupują ogólne skłonności do recydywy oraz część specyficznych faktorów przestępczości seksualnej. Przykładami historycznych czynników aspołecznych są: młody wiek, problemy z zatrudnieniem, zażywanie narkotyków i alkoholu, zaburzenia zachowania w dzieciństwie, przemoc o charakterze innym niż seksualna w wywiadzie, wcześniejsze przestępstwa i naruszenie toku postępowania wykonawczego. W tej grupie wymienia się niezdolność do tworzenia stabilnych relacji intymnych, impulsywność, niestabilność emocjonalną, niestałość w relacjach z partnerem lub nieprawidłowe postawy wobec partnera. Wśród czynników seksualnych należy szczególną uwagę zwrócić na: wcześniejsze przestępstwa seksualne i ich liczbę, charakter przestępstw, nasilenie przemocy, eskalację i różnorodność przestępstw, typ ofiary oraz wykorzystywanie przymusu fizycznego lub psychicznego. Z ryzykiem recydywy należy wiązać: wykorzystywanie ofiar płci męskiej (szczególnie jeżeli ofiarami są dzieci), przestępstwa,

${ }^{24}$ T. Ward, A.R. Beech, An Integrated Theory of Sexual Offending, [w:] Sexual Deviance: Theory, Assessment and Treatment, red. D.R. Laws, W.T. O'Donohue, New York 2008, s. 21-36

25 R. Darjee, K. Russell, What clinicians need to know before assessing risk in sexual offenders, „Advances in Psychiatric Treatment” 18, 2012, z. 6, s. 467-478.

Nowa Kodyfikacja Prawa Karnego 54, 2019

(C) for this edition by CNS 
których ofiary są niespokrewnione lub obce, sytuację, w której ofiarami są jednocześnie dorośli i dzieci ${ }^{26}$.

W drugiej grupie czynników ryzyka, tak zwanych stabilnych-dynamicznych, wymienia się: problemy emocjonalne, interpersonalne, poznawcze, społeczne i seksualne. Wskazane kategorie można zaliczyć do psychicznych cech jednostki, które mogą zmieniać się powoli wraz z upływem czasu, także w reakcji na leczenie. Stabilne czynniki dynamiczne pozwalają uzyskać odpowiedź na pytanie, dlaczego dana osoba popełniła określony rodzaj przestępstwa. Ich analiza służy także do ewaluacji konkretnych działań podjętych wobec skazanego (ocena reakcji na terapię), służy do oceny poziomu zmiany skazanego w kluczowych obszarach funkcjonowania społecznego ${ }^{27}$. W tej grupie czynników nie możemy zapominać także o predyspozycjach genetycznych, doświadczeniu z dzieciństwa, procesie rozwoju w okresie dojrzewania i istotnych wydarzeniach w wieku dorosłym. Stabilne-dynamiczne czynniki ryzyka związane są z seksualnymi zainteresowaniami, seksualną samoregulacją i postawą sprawcy. Istotne są tutaj również funkcjonowanie społeczno-afektywne oraz ogólna samoregulacja sprawców tego typu zachowań. Czynniki te są stosunkowo stabilne w czasie, jednak w wyniku stosowanej terapii i wraz z upływem czasu mogą się zmieniać. Są to najważniejsze bodźce, na których należy skupić się w trakcie oddziaływania na sprawców. Stabilne-dynamiczne czynniki ryzyka to między innymi: poczucie żalu/wrogość, sprzeciw wobec postępowania wykonawczego i organów wykonawczych, niskie umiejętności rozwiązywania problemów, impulsywny styl życia, brak intymnych pod względem emocjonalnym związków z dorosłymi, dewiacje seksualne, postawy wspierające przestępstwo (negatywne grupy odniesienia, funkcjonowanie w grupach marginalnych), seksualizacja przemocy. Warto także zwrócić uwagę w tym fragmencie na tak zwany mechanizm zaprzeczenia, uznawany za czynnik ryzyka. Taka postawa jest częstym

26 R.K. Hanson, A. Harris, Where should we intervene? Dynamic predictors of sexual offence recidivism, „Criminal Justice and Behaviour” 2000, nr 27, s. 6-35; oraz A.R. Beech, D. Fisher, D. Thornton, Risk assessment of sex offenders, „Professional Psychology: Research and Practice" 2003, nr 34, s. 39-52.

27 R.E. Mann, R.K. Hanson, D. Thornton, Assessing risk for sexual recidivism: some proposals on the nature of psychologically meaningful risk factors, „Sexual Abuse: A Journal of Research and Treatment" 2010, nr 22, s. 191-217.

Nowa Kodyfikacja Prawa Karnego 54, 2019

(C) for this edition by CNS 
mechanizmem u sprawców przestępstw seksualnych. Warunkują ją różne okoliczności (na przykład wstyd, chęć utrzymania kontaktów społecznych, dążenie do zachowania szacunku do siebie, brak samoświadomości). Zaprzeczanie i pomniejszanie często są wymieniane jako czynniki ryzyka, zwłaszcza w perspektywie wpływu na indywidualne zaangażowanie w leczenie $\mathrm{i}$ inne aspekty postępowania wykonawczego. Powinno się także zwracać uwagę na deficyty w funkcjonowaniu interpersonalnym i społecznym oraz niewiedzę dotyczącą życia seksualnego.

Trzecia grupa to czynniki ostre-dynamiczne, mające bezpośredni związek z ryzykiem powrotu do zachowań przestępnych o podłożu seksualnym. Wśród tych czynników mamy wyzwalające (czynniki destabilizujące, odhamowujące i wyzwalające), które wpływają na stabilne dynamiczne czynniki ryzyka, prowadząc daną osobę do znalezienia się w sytuacji lub stanie, kiedy wystąpi prawdopodobieństwo ponownego popełnienia przestępstwa. Tutaj umieszczane są czynniki sytuacyjne lub określające stan umysłu sprawcy o takim charakterze, który może skłaniać go do ponownego popełnienia przestępstwa. Ostre czynniki pozostają w najbliższym związku czasowym z przestępstwem i sugerują bezpośrednie zagrożenie jego popełnieniem. W praktyce trudno je w sposób zupełnie pewny zidentyfikować. Przyjmuje się, że do tej grupy czynników ryzyka zaliczamy: eskalację używania alkoholu i narkotyków, pogorszenie relacji intymnych i innych, utratę wsparcia społecznego, nasilenie kontaktów z osobami aprobującymi postawy aspołeczne i sprzyjającymi przestępstwom seksualnym, utrata zatrudnienia i problemy w pracy, stres, dostęp do potencjalnych ofiar przez stwarzanie możliwości, zmianę okoliczności lub zmniejszenie czujności otoczenia. Tutaj możemy jeszcze wymienić czynniki odzwierciedlające stan umysłu danej osoby lub sytuację, która przybliża możliwość przestępstwa seksualnego: nadmierne pochłonięcie kwestią seksu (fantazje o tematyce dewiacyjnej lub niedewiacyjnej), nastrój/stan psychiczny (nasilenie lęku, depresji, wrogości, frustracji, objawów psychotycznych), dowody na to, że dana osoba planuje przestępstwo lub stwarza sobie możliwość popełnienia przestępstwa (na przykład noszenie przy sobie broni lub krążenie samochodem po mieście), brak współpracy podczas terapii (niezgłaszanie się na spotkania, niedostosowywanie się do warunków, złe zachowanie podczas sesji), używanie alkoholu lub narkotyków jako dysfunkcjo-

Nowa Kodyfikacja Prawa Karnego 54, 2019

(C) for this edition by CNS 
nalna metoda radzenia sobie z negatywnymi emocjami, izolacja, coraz bardziej chaotyczny styl życia ${ }^{28}$.

W szacowaniu ryzyka zachowań kryminalnych zwraca się uwagę na tak zwane czynniki ochronne. Kompleksowe metody szacowania ryzyka starają się także uwzględnić ten aspekt funkcjonowania sprawców i otoczenia (na przykład Structured Assessment of Protective Factors - SAPROF ${ }^{29}$. Wyróżnia się dwa rodzaje czynników ochronnych: osobiste zasoby i zewnętrzne wsparcie/kontrola. Osobiste zasoby to głównie zdolność do radzenia sobie ze stresem i konfliktami interpersonalnymi. Umiejętność nawiązywania odpowiednich do wieku relacji intymnych oraz angażowanie się w relacje z innymi. Elementy ochronne mogą być obecne przez całe życie lub wykształcić się dzięki pomocy, wsparciu i konkretnej interwencji. Bardzo ważne jest zdiagnozowanie tych czynników i uchwycenie wszystkich tego rodzaju umiejętności, zdolności i inklinacji. Te czynniki są podstawą do rozpoczęcia prospołecznego życia, ugruntowują postawę, w której potrzeby sprawcy (związki, funkcjonowanie zawodowe, przyjaźnie, poczucie własnej wartości, zdobywanie dóbr materialnych) zaspokajane są w sposób niewiążący się z popełnianiem przestępstw. Poza wewnętrznymi zasobami do czynników ochronnych zaliczamy wsparcie z zewnątrz, relacje i okoliczności, które mogą uchronić przed ponownym popełnieniem przestępstwa. W zidentyfikowaniu indywidualnych czynników ochronnych pomocne może być przyjrzenie się tym okresom życia sprawcy, w których nie popełniał on przestępstw, oraz ocena pozytywnych reakcji na wcześniej stosowane schematy odziaływania terapeutycznego i resocjalizacyjnego.

28 R.K. Hanson, A. Harris, op. cit., s. 6-35; oraz R. Darjee, K. Russell, op. cit., S. $467-478$.

29 SAPROF — narzędzie, którego pierwsza wersja powstała w 2007 roku w Klinice Van Der Hoeven w Utrechcie (Holandia) we współpracy z Kliniką Pompe i Uniwersytetem w Mastricht jako uzupełnienie do HCR-20V3 i podobnych narzędzi. Pozwala ono na ustrukturyzowaną, profesjonalną ocenę czynników chroniących przed przemocą, kładąc nacisk na zasoby i mocne strony osoby badanej. Pozwala też rozwijać odpowiednie strategie, rozwiązania i plany ukierunkowane na zmniejszenie ryzyka przemocy i wzmocnienie mocnych stron osoby, u której istnieje ryzyko przemocy. Polska wersja narzędzia SAPROF powstała w 2016 roku. Szerzej http://www.ryzykoprzemocy.pl/saprof (dostęp: 1.03.2020).

Nowa Kodyfikacja Prawa Karnego 54, 2019

(C) for this edition by CNS 
Aktualnie mamy do czynienia z próbą holistycznego wykorzystania zalet wszystkich stosowanych metod szacowania ryzyka. Zauważalną zmianą jest próba powiązania wartości wszystkich stosowanych w praktyce metod, co pozwala wyodrębnić dwa schematy oceny ryzyka. Pierwszy to czysta predykcja koncentrująca się na ustaleniu prawdopodobieństwa wystąpienia określonych zdarzeń w danym przedziale czasu. Drugi schemat to próba ustalenia czynników, które mogą redukować niebezpieczeństwo wystąpienia niepożądanych zdarzeń ${ }^{30}$. Wskazane schematy mogą być realizowane w ramach podejścia idiograficznego, które koncentruje się na indywidualnych czynnikach ryzyka. Ten sposób oceny to rodzaj rozumowania przyczynowego, koncentrujący się na konkretnym przypadku, zmierzający do pełnego zrozumienia jednostkowego zdarzenia i ograniczony w swoim zasięgu do tego zdarzenia. Jego przeciwwagą jest model nomotetyczny, który szuka wyjaśnień raczej pewnej klasy sytuacji czy cech niż pojedynczego przypadku. Chodzi tutaj o porównanie z normami populacyjnymi, co do których ocena jest bardziej ekonomiczna i koncentruje się na pewnej grupie czynników wyjaśniających (przy czym w tym wypadku mamy do czynienia raczej z wyjaśnieniem cząstkowym, o bardziej uniwersalnym zastosowaniu — wybija się rzetelność tak gromadzonego materiału - a nie kompletną analizą idiograficzną, której zaletą jest wysoka trafność). Niezależnie od problemów metodologicznych zagadnienie szacowania ryzyka to przyszłość w zakresie polityki kryminalnej i praktyki funkcjonowania systemów penitencjarnych, probacyjnych i miejsc internacji niebezpiecznych sprawców. Warto odnotować, że w 2016 roku rozpoczęliśmy proces implementacji narzędzi HCR-20 V3 i SAPROF w polskich instytucjach sądowo-psychiatrycznych, to jest na oddziałach sądowych Szpitala dla Nerwowo i Psychicznie Chorych w Starogardzie Gdańskim i Regionalnym Ośrodku Psychiatrii Sądowej w Starogardzie Gdańskim. To początek wprowadzania tego rodzaju narzędzi i technik do naszego postępowania wykonawczego ${ }^{31}$.

${ }^{30}$ K. Heilbrun, Prediction versus Control Mathods Relevant to Risk Assessment: The Importance of Legal Decision-making Context, „Law and Human Behavior” 21, 1997, nr 4, s. 349-355.

31 http://www.ryzykoprzemocy.pl/przemoc-projekty-badawcze (dostęp: 10.03.2020).

Nowa Kodyfikacja Prawa Karnego 54, 2019

(C) for this edition by CNS 


\section{Bibliografia}

Andrews D.A., Bonta J., The Psychology of Criminal Conduct, New Providence 2010.

Andrews D.A., Bonta J., Hoge R.D., Classification for effective rehabilitation. Rediscovering psychology, „Criminal Justice and Behavior” 17, 1990, nr 1.

Barczykowska A., [w:] A. Barczykowska, S. Dzierzyńska-Breś, M. Muskała, Systemy oddziatywań resocjalizacyjnych Anglii i Stanów Zjednoczonych Ameryki, Poznań 2015

Barczykowska A., Zastosowanie modelu $R-N-R w$ diagnozie resocjalizacyjnej dorostych sprawców przestęstw — rozwiązania angielskie, „Studia Edukacyjne” 2015, nr 34.

Beech A.R., Fisher D., Thornton D., Risk assessment of sex offenders, „Professional Psychology: Research and Practice" 2003, nr 34.

Beech A.R., Ward T., The integration of etiology and risk in sexual offenders: A theoretical framework, „Aggression and Violent Behavior” 10, 2004, z. 1.

Chojecka J., Model dla wszystkich? Spory wokół koncepcji szacowania ryzyka recydywy, „Resocjalizacja Polska” 2014, nr 7.

Cooter R., Ulen T., Ekonomiczna analiza prawa, przeł. J. Bełdowski et al., red. J. Bełdowski, K. Metelska-Szaniawska, Warszawa 2009.

Craig L.A., Browne K.D., Metody oceny ryzyka recydywy przestęstw seksualnych, „Dziecko Krzywdzone. Teoria, badania, praktyka” 6, 2007, nr 1.

Cullen F.T., Gendreau P., From Nothing Works to What Works: Changing Professional Ideology in the 21st Century, ,The Prison Journal” 15, 2001.

Darjee R., Russell K., What clinicians need to know before assessing risk in sexual offenders, „Advances in Psychiatric Treatment” 18, 2012, z. 6

Giddens A., Socjologia, przeł. A. Szulżycka, Warszawa 2012.

Gierowski J.K., Czynniki ryzyka i opiniowanie przemocy u adolescentów, „Farmakoterapia w Psychiatrii i Neurologii” 2005, nr 2.

Hanson R.K., Harris A., Where should we intervene? Dynamic predictors of sexual offence recidivism, „Criminal Justice and Behaviour” 2000, nr 27.

Heilbrun K., Prediction versus Control Mathods Relevant to Risk Assessment: The Importance of Legal Decision-making Context, „Law and Human Behavior” 21, 1997, $\mathrm{nr} 4$.

Janus M., Szulc A., Seksuologiczne narzędzia diagnostyczne w Polsce i na świecie, „Seksuologia Polska" 13, 2015, nr 1.

Kalisz T., Kara pozbawienia wolności w perspektywie założeń modelu $R-N-R$ (Risk-Need-Responsivity), [w:] O stabilność kodeksu karnego w świetle realiów. Księga Jubileuszowa Profesora Stanisława Hoca, t. 1, red. D. Mucha, Opole 2018.

Kalisz T., Kara pozbawienia wolności w perspektywie zasady ultima ratio. Oczekiwany zmierzch więzienia?, [w:] Prawo karne jutra — między pragmatyzmem a dogmatyzmem, red. W. Zalewski, Warszawa 2018.

Kądziołka K., Społeczno-ekonomiczne determinanty przestępczości powrotnej. Wybrane problemy stosowania metod ilościowych do identyfikacji zależności, „Współczesna gospodarka" 7, 2016, nr 1 .

Nowa Kodyfikacja Prawa Karnego 54, 2019

(C) for this edition by CNS 
Mann R.E., Hanson R.K., Thornton D., Assessing risk for sexual recidivism: some proposals on the nature of psychologically meaningful risk factors, „Sexual Abuse: A Journal of Research and Treatment" 2010, nr 22.

Rogers R., The Uncritical Acceptance of Risk Assessment in Forensic Practice, „Law and Human Behavior" 24, 2000, $\mathrm{nr} 5$.

Stańdo-Kawecka B., O koncepcji resocjalizacji w polskiej literaturze naukowej polemicznie, „Probacja” 2010, nr 1.

Stańdo-Kawecka B., Wybrane problemy profesjonalizacji organów probacyjnych $i$ klasyfikacji sprawców oddanych pod dozór do grup ryzyka, „Nowa Kodyfikacja Prawa Karnego" 33, 2014.

Sztuka M., Anachronizm i aktualność. Idea resocjalizacji w sporze o nowoczesność, Kraków 2013.

Sztuka M., Efektywność oddziaływań w zorientowanym korekcyjnie modelu instytucji penitencjarnej. Doświadczenia amerykańskie, „Czasopismo Prawa Karnego i Nauk Penalnych" 2007, z. 1.

Ward T., Beech A.R., An Integrated Theory of Sexual Offending, [w:] Sexual Deviance: Theory, Assessment and Treatment, red. D.R. Laws, W.T. O'Donohue, New York 2008.

Welento-Nowacka A., Zastosowanie oraz zatożenia teoretyczne narzędzi opartych na modelu ustrukturyzowanej oceny ryzyka wystapienia zachowań zwiazanych z przemocq w praktyce klinicznej, „Psychiatria” 14, 2017, nr 1.

Wójcik D., Stosowanie w postępowaniu karnym narzędzi diagnostyczno-prognostycznych stużących oszacowaniu ryzyka powrotności do przestępstwa, Warszawa 2012, https://www.iws.org.pl/pliki/files/IWS_W\%C3\%B3jcik\%20D_Ocena\%20ryzyka\%20ponownej\%20przest.pdf.

\section{Tools for estimating the risk of a return to crime. An indispensable instrument of enforcement proceedings}

\section{Summary}

The aim of the study is to discuss the most important problems related to the assessment of the level of risk of recidivism, taking into account actuarial methods, psychometric methods, and idiographic clinical trials. The point is to show tools that are intended not only to predict criminal behavior, but also to be an indicator of effective interventions aimed at social reintegration of convicts and thus a permanent form of preventing recidivism. These instruments are of particular importance for controlling crimes committed under the influence of sexual preference disorders.

Keywords: R-N-R model, risk estimation, criminal punishment, sexual offenses. 